\title{
A factual analysis of sustainable opportunity recognition of immigrant entrepreneurship in Finnish Lapland: Theories and practice
}

\author{
Nafisa Yeasmin ${ }^{1}$ (D), Timo Koivurova² (iD
}

\begin{abstract}
Immigrant entrepreneurs are in a disadvantaged position in the Arctic Lapland. According to previous studies (see Yeasmin, 2016), there are many factors that hinder the sustainability of immigrant business. Immigrant entrepreneurs lack socioeconomic and political knowledge along with many other hindrances. Broadening knowledge and combining strong and weak ties (Granovetter, 1985) are positive factors among many other mixed factors relating to operating a business successfully. Sustainable immigrant entrepreneurship practices require legitimacy between entrepreneurial actions and opportunity recognition. Research on sustainable immigrant entrepreneurship does not fit into a single literature body and it is difficult to make a single model for the growth potential of immigrant entrepreneurship in Lapland (Yeasmin, 2016). Therefore, the focus of this study is to create an integrated value for immigrant entrepreneurs by combining the CSR theory and mix embeddedness theory, and find an alternative concept of practice for understanding the drivers that can sustain the micro businesses of immigrants in Lapland and can give an explanation on opportunities recognition which can be embedded so as to get access to the necessary entrepreneurial capital (local, regional or national). This study argues that the degree of CSR embeddedness could be developed as a component of mixed embeddedness supports the discovery of institutional, social and economic opportunity strategy amongst immigrant entrepreneurs. Conceptually, this study explores adaptive factors that immigrant entrepreneurs are determined to embed (whether knowingly) as mixed practices that create entrepreneurial success.

Keywords: mixed-embeddedness, sustainable, entrepreneurship, immigrant, CSR, opportunity recognition
\end{abstract}

\footnotetext{
1 Nafisa Yeasmin, Post-doc Researcher, Arctic Centre, University of Lapland, Arktikum House, Pohjoisranta 4, 96100 Rovaniemi, Finland, e-mail: nafisa.yeasmin@ulapland.fi (ORCID ID: 0000-0003-4711-2387)

2 Timo Koivurova, Research Professor/Director Arctic Centre, University of Lapland, Arktikum House, Pohjoisranta 4, 96100 Rovaniemi, Finland, e-mail: timo.koivurova@ulapland.fi (ORCID ID: 0000-0002-3548-5883)
}

Received 18 March 2018; Revised 10 January 2019; Accepted 30 January 2019 


\section{INTRODUCTION}

Immigrants are a marginalized group in the labor market in Finnish Lapland, since the unemployment rate is high among immigrant jobseekers. Immigrant entrepreneurs are also in a disadvantaged position in the Arctic Lapland (Yeasmin, 2016). According to previous studies (Yeasmin, 2016), there are many factors that hinder the sustainability of immigrant business. Immigrant entrepreneurs lack socio-economic and political knowledge along with many other hindrances. Broadening knowledge and combining strong and weak ties (Granovetter, 1985) are positive factors among many other mixed factors relating to operating a business successfully. Sustainable immigrant entrepreneurship practices require legitimacy between entrepreneurial actions and societal expectations.

Some other previous studies indeed showed that the entrepreneurial talent of immigrants might not be fully utilized in the host countries (Hjerm, 2004; Kloosterman et al., 1999; Frederick, 2008). Perhaps at some cost, it is possible to "close the gap" between immigrant entrepreneurs and the economic growth of their enterprises in the host countries (The European Commission, 2003; Frederick, 2008; Frederick, 2006). On the one hand, immigrants need to broaden their knowledge, while on the other hand, it is important to find out the disadvantages that inhibit the drive for selfemployment by immigrants, such as 1) social and individual disadvantages, 2) geographic disadvantages, 3) cultural disadvantages 4) economic disadvantages and 5) structural disadvantages (European Commission, 2003). Perceptions of Corporate Social Responsibility (CSR) amongst immigrant, small entrepreneurs, are topical in the current study. Micro and small companies are not involved in the desired way and are not accountable for their impact on society and the environment. However, this research finds that their contribution to CSR would support entrepreneurial success and sustainability, which very much depends on social, economic and institutional interplay, and are the basic grounds of entrepreneurial success according to the mixed embeddedness theory (Rath et al., 2002; Rath, 2005).

This study is a combination of CSR practice and mixed embeddedness. The context of this integrated theory could enable micro and small enterprises to create tools for sustaining their entrepreneurial path in Lapland. CSR is a business approach for business sustainability that can ensure shared values between all stakeholders by delivering economic, social and institutional benefits. On the other hand, these are three main components of mixed embeddedness for finding main characteristics of the opportunity structures.

According to our case study, the adoption of CSR by the immigrant entrepreneur is a significant phenomenon, which needs research attention 
in the Arctic. Immigrant entrepreneurs have mixed attitudes toward adopting CSR. The immigrant entrepreneurs who took part in this study knew very little about CSR. There is not much previous research regarding CSR in micro and small-scale, immigrant enterprises in Finland. According to the mixed embeddedness theory, the demand and supply side of the ethnic market has an effect on immigrant entrepreneurship (Rath et al., 2002, p 33). The concept of mixed embeddedness focuses on those factors (strong and weak ties), explaining the success of immigrant entrepreneurship (Portes, 1995; Rath, 2005). The focus of this study is to create integrated value for immigrant entrepreneurs, by combining CSR and mixed embeddedness, which can sustain micro businesses of immigrants in Lapland.

The CSR efforts of an immigrant's business can indeed be influenced in various ways by internal and external determinants: either for benefit or institutional, personal and external factors (Keinert, 2008, p. 139). Smallsized businesses have low public visibility, and the lack of a permanent establishment strategy isolates the individual entrepreneurs from the community, which compound a negative influence on their perceptions of CSR (Azmat \& Samaratunge, 2009). However, in the context of immigrant businesses in Lapland, the theoretical positions of immigrant entrepreneurs and their success depend on various theories rather than any single theory. This study argues that the degree of CSR embeddedness is just a component of mixed embeddedness support discovering institutional, social and economic opportunity strategy among immigrants' entrepreneurs. This study explores the adaptive factors that immigrant entrepreneurs are determined to embed (whether knowingly) as mixed practices that create entrepreneurial success.

This study is based on ethnographic observation along with in-depth interviews of three enterprises and two in-depth interviews of immigrant entrepreneurs. They have followed mixed theories towards profit, independence, and resource availability. Although they have different conceptions about business success, reputation and business strategy, they have been operating their businesses successfully for more than three years

\section{THEORETICAL FRAMEWORK}

Lapland is a sparsely populated area and new immigrant-receiving region. There are different categories of immigrants (like refugees, asylum seekers, students, job seekers, etc.). "Immigrants are a vulnerable group in the labor market since the unemployment rate among immigrants in Lapland is higher than that among locals" (Yeasmin, 2016). The regional characteristics also differ from the rest of Finland because of its Arctic feature. Research on 
sustainable immigrant entrepreneurship (Ibid.) does not fit into a single literature body and it is difficult to make a single model for the growth potential of immigrant entrepreneurship in Lapland (Yeasmin, 2016). Therefore, it is always important to combine some concepts for the tremendous potential of the application of business theories of immigrants in Lapland, since the extreme Arctic characteristics of Lapland and Finnish bureaucracy hinder business opportunity for newcomers (Yeasmin, 2016). We have chosen CSR and the mixed embeddedness theory to assess our empirical materials.

CSR is a commitment, obligation and action that is planned and implemented by entrepreneurs for assessing and evaluating business benefits (Coombs \& Holladay, 2012, p. 29). CSR has been defined as a "trend that appeals to change of business orientation from short-term to long-term goals and from maximum to optimum profit" (Moravcikova et al., 2015).

CSR identifies and embeds mixed strategies to find ways and opportunities for motivation to operate a business (Rohweder, 2004, pp. 81-98). Positive images and influences of a business embed a steady precondition towards the successful operating of a company (Kotler \& Lee, 2005; Santos, 2011). A good reputation requires a strategic plan to attract stakeholders, and build values and trustful relations among stakeholders for finding the best opportunity for business development. An entrepreneur can reduce operating cost by embedding vacancy chains in different forms that include the situational analysis of work phases and resources to decrease production costs, i.e., market research on getting cheaper raw materials, recycling materials, better value transportation, and finding more opportunities and support from the government, etc.

Some previous studies have also embedded the personal competencies of entrepreneurs to incorporate and implement the CSR process in business practice (Santos, 2011; Rashid \& Ibrahim, 2002). A positive mindset of entrepreneurs towards CSR practices, challenges and opportunity embed mixed competencies from the entrepreneurs, i.e., social and academic skills, socio-cultural values and beliefs, learning skills, good behavior and attitudes, etc.

CSR in Finland highlights the relations among stakeholders, networks, public leaders. CSR orientation has been discussed as a minimal issue in Finland that is more often related to business taxes than ethics (Juholin, 2004; Gjølberg, 2010). By paying taxes, entrepreneurs are decreasing social security costs and this has been seen as a CSR practice. However, entrepreneurs have been pressured to comply with guidelines and meet social responsibility by considering recruiting working-age minority populations, e.g. immigrants and the local labour market (Suutari et al., 2016), which is also motivation for anti-discrimination (Migration Policy Group, 2002) and CSR initiates (Ram \& Smallbone, 2003) for larger companies (a common good for society). 
Therefore, corporate philanthropy and charity are compensated through a sympathy contribution in Finland. CSR practice is more common among big companies in Finland; however, it is equally important to embed CSR practice in micro-sized companies for the successful continuation of business. CSR perception is a way to encourage responsible behavior and individual values and cultivate the virtues of entrepreneurs in Finland (Wang, 2011).

Explicit CSR practice is embeddedness of trust, norms, rules and customs that create obligations, commitment and the motivation to find opportunities for business success. Such motivation of entrepreneurs is important for good will, human (personal) values and social inclusion (social status) of smallsized immigrant businesses. CSR activities help entrepreneurs to understand institutional, social and economic value through the realization that the recognition of opportunity is essential for business operation (MIT, 2011).

If we explain the concept of mixed embeddedness, it is not that different from the concept of CSR. There are diverse and numerous definitions of CSR (Mohammed \& Leponiemi, 2009) but our concern is to explore interconnectedness between these two concepts for the clarity of analyzing our empirical materials. According to Polanyi, although business is an economic activity, there are many non-economic institutions, factors and provisions that support economic growth (Polanyi, 1968). Granovetter argued in 1985 that every economic activity is embedded in society and concrete societal relations - human behavior, personal relationship, networking with traders and customers. Kloosterman et al. (1999) also combined various values with the skills of entrepreneurs for the development of informal economic strategies. Mixed embeddedness is a conceptual framework for exploring how immigrant entrepreneurs encompass the crucial interplay between social, economic and institutional contexts. They argued that entrepreneurship is a competitive phenomenon; therefore, it demands competitive and mixed entrepreneurial strategies. He has combined a mutual relation of high and low threshold markets with different levels of human capital for measuring high and low growth potentials. The concept focuses on an economic, social and institutional opportunity structure and immigrant entrepreneurs are analyzed for the growth potential of the business and their understanding of local markets (Price \& Chacko, 2009). In this theory, the success of business depends on local market analysis (location), institutional controls and finding access to opportunities, which are very much interconnected with the characteristics, personal experiences and competencies of immigrant entrepreneurs.

Therefore, integrated concepts focus on economic survival and the ethics of business based on interactions and economic, social and institutional connections, which influence their success in a relevant space and time (Figure 1). These concepts encompass multiple aspects of opportunity 
structures that are related to the sustainability of immigrant businesses, i.e., the strategic flexibility, social capital and human capital of entrepreneurs.

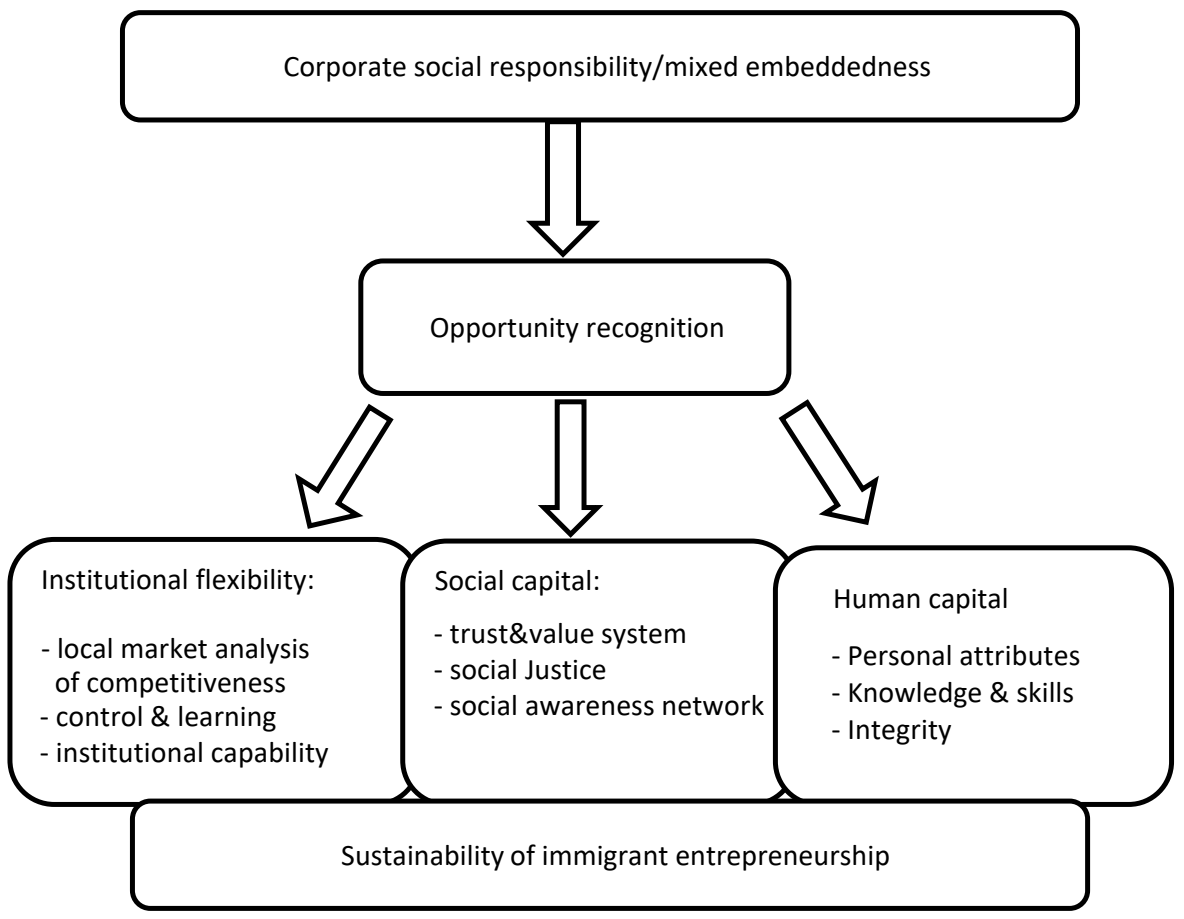

Figure 1. Relation between business sustainability with CSR and the mixed embeddedness theory

\section{Integrated concept: Interconnectedness between CSR and the mixed embeddedness theory}

In the mixed embeddedness theory, social embeddedness is important. However, time and space/place trajectories are equally important for sustaining a business. Proper time and a proper consumer market allow the success of a business according to Kloosterman (2003). Why are large spaces needed in the market for a certain business? Are the entrepreneurs themselves able to outsource the risk of the business? Do the existing rules and regulations allow such business? Does starting the business require any market research on certain products or is there already market research available? This information can be embedded in the entrepreneurial spirit. The time and space concept (Swedberg, 1994, p. 255) can embed market 
demand by inspiring entrepreneurs to think about resource capital (financial, human, social and ethnic).

The time and space concept includes a specific opportunity structure that can help identify the resources of their place of settlement, its geographic location and support building companionship with neighbors. Through these mixed approaches, immigrant entrepreneurs can relate their resources to the opportunity-driven structure. All the entrepreneurs in our study have some weak and strong performance levels that have an impact on the entrepreneurial process. This particular mix of both strong and weak ties benefits entrepreneurial survival by finding structural holes, which necessitates discovering opportunity structures for filling up the holes (Elfring \& Hulsink, 2004).

Therefore, we find that the specific sets of resources of individual immigrant entrepreneurs postulate a relationship between the opportunity structures by adding a dynamic interpretation of economic, social and institutional incorporation towards entrepreneurial success. Both CSR and the mixed embeddedness theories stand for the growth potential of enterprises and integrated policies back up a management style for entrepreneurs that enhance the possibility of long-term solutions and success of enterprises. The standpoints of the integrated concept end with opportunity recognition (see Figure 2). The main three components of integrated concept (institutional, economic and social) rely on strong and weak ties. These ties are positively related to entrepreneurial performances, socio-economic and institutional surroundings of entrepreneurs which could be different in a time-space context.

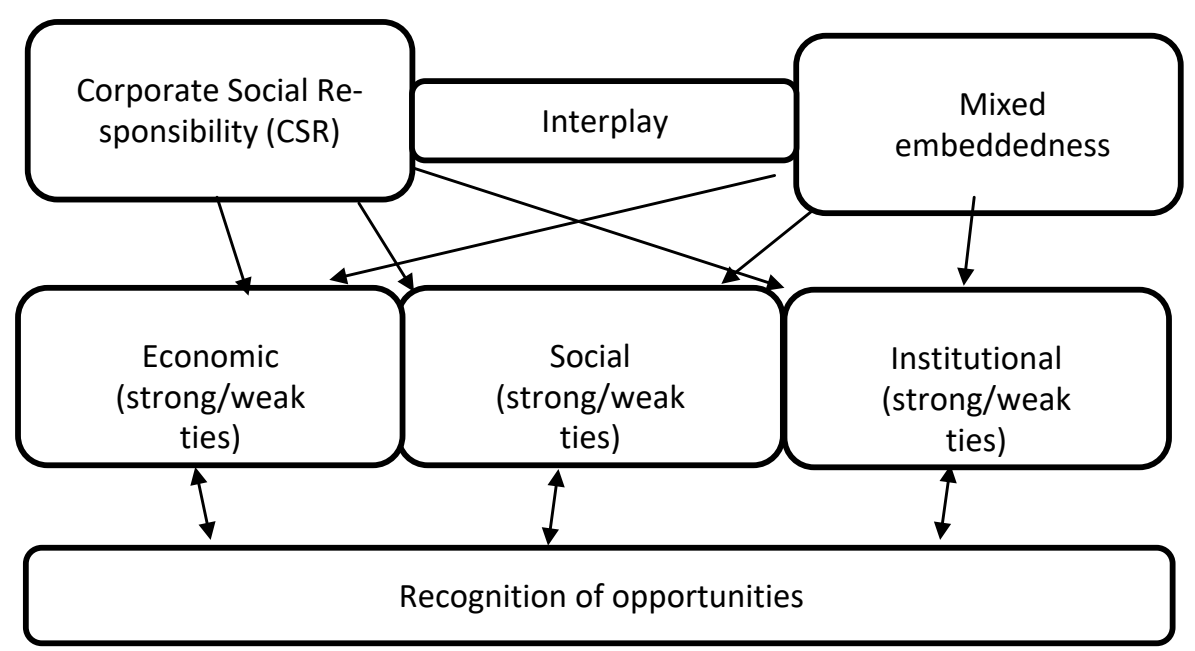

Figure 2. Interconnectedness between opportunity structures with both theories 
Economic dimension: As per the mixed embeddedness theory, long-term growth for micro and small-scale enterprises can be measured by looking at different structural trends in a specific market (Kloosterman, 1999). The economic growth of an enterprise depends not only on a promising market but also on human capital and the orientation of human capital towards broader markets. On the other hand, the economic viewpoint of creating profit and values of an enterprise in CSR practice means good performance of entrepreneurs towards stakeholders, e.g., designing a supply chain and good services for the consumer. Enhancing positive attitudes towards all related stakeholders in a responsible way can build a corporate culture among stakeholders in the community where they reside (Nelson \& Prescott 2003).

Satisfying customers by knowing their needs increase relations with stakeholders. This is not only limited to generic economic functions (Handelman, 2006), but also the survival and success of the enterprise. For instance, achieving economic and non-economic goals depends on relations and networking between different groups of stakeholders, not only consumption, investment and supply (Pirsch et al., 2007). This relationship should be extended to a stakeholder's identity, interests, ideology, values and expectations (Preuss, 2011; Crane et al., 2004; Den-Hond \& Bakker, 2007; Granovetter, 2005).

Immigrant entrepreneurs' individual competency to know the market competition, price and cost; monitor the market; utilize the capacity of existing support on human resources; and have negotiation and marketing skills, are equally important for the success of a business. Entrepreneurial skills support balancing ethical and trust-based responsibility among multiple stakeholders (Beekun \& Badawi, 2005). As the mixed embeddedness theory describes, the success of some businesses requires a relatively high-skilled human capital, while some other businesses can attain business growth with small-scale, low-skilled human capital and physical fitness for sustaining long hours of hard work (Kloosterman, 1999). Exploring the category of business by immigrant entrepreneurs can be a cause of success and failure of the business (Waldinger et al., 1990).

Social dimension: An enterprise should have other measures of success than just financial performances. Under the CSR theory, all enterprises have a responsibility and accountability towards social effects. Immigrant entrepreneurs in small-scale and micro-level businesses do not have any philanthropic responsibility whereas macro-level enterprises have an obligation towards well-being among society and stakeholders. However, some scholars describe that the fact that immigrant and micro-enterprises pay taxes means they are contributing to society since taxes have been used for the development and well-being of the community and people (Rohweder, 2004; Uddin et al., 2008). 
According to the social justice theory, CSR practice includes the social responsibilities of the enterprises, e.g., the relationship between society and entrepreneurs, and integrating social demands and the ethical obligation to society. This type of social responsibilities could be I) macrosocial and II) microsocial (Garigga \& Melé, 2004). Macro enterprises solve social problems by creating harmony amongst the community and individuals. Sometimes society also demands a responsible corporate body (Davis, 1960).

Microsocial-concept is not a philanthropic ideal but rather an authentic norm of attitudes and behaviors of community members towards entrepreneurs and vice versa (Garigga \& Melé, 2004). The overall perception of social justice is to hold the common good of society, which has a referential value for CSR (Mahon \& McGowan, 1991; Velasquez, 1992). The social dimension of CSR illustrates the positive contribution of enterprises to the well-being of society, and a harmonic way to live together (Melé, 2002).

According to Sulmasy (2001), the common good is a convincing interpretation of the knowledge of human nature that permits the circumnavigation of cultural relativism (Sulmasy, 2001), and the convergence of religious, political and philosophical thought (Donaldson \& Dunfee, 2000, p. 441). Some scholars think that living and working together in a community means a common good for society (Goodpaster, 1999; Kaku, 1997; Yamaji, 1997). If we assess all this thought on the social responsibility of entrepreneurs, we find that immigrant entrepreneurs can play a microsocial role through the convergence of religious and cultural thought of social members towards immigrants. Immigrant entrepreneurs can help society by integrating themselves in that society. Self-employment of immigrants is an advantage both for the local economy and for the community. Since, in spite of their different cultural (Azmat \& Zutshi, 2012) and religious backgrounds, if they can live and work together with the local society, it is a common good for all in the society.

According to previous research findings, although immigrant communities are willing to adjust their home country culture, customs and family values, they still try to maintain some weak or strong linkage with their background culture whether it has a positive or negative impact on operating a business in the host country (Hamilton et al., 2008). Proper integration is sometimes good for business growth.

In the mixed embeddedness theory, most of the immigrant entrepreneurs kept a strong relationship with ethnic capital rather the common social capital of the host country. Immigrant entrepreneurs are usually dependent on ethnic capital by searching for employees and customers from within the ethnic community, and their network is mostly ethnically-based which does not support proper acculturation in the host society. They need to apply 
a specific kind of social embeddedness that can build a trust relationship with local stakeholders (Kloosterman, 1999; Kloosterman, 2010).

In this case, the chances of becoming successful and the continuation of the business are rather slim (ibid.). Therefore, they lack opportunity knowledge and control over access to social capital. It can also limit their social competition and monitoring skills over business opportunity. As Kloosterman (1999) points out "being embedded in heterogeneous social networks may even constitute a prerequisite for starting a business there, as information of new consumption habits is essential." Social capital formation is a skill of the entrepreneur, and business strategy requires the professional competencies of entrepreneurs. It does not matter whether this competency has been achieved from the host country or the country of origin (Taylor \& Leonard, 2002).

A skilled entrepreneur can combine a heterogeneous social network to support business growth and continuation. According to Granovetter (1985), entrepreneurial outcomes are achieved through social embeddedness, whilst in a previous study, the social embeddedness of an entrepreneur is a behavioral expression of social skills of a human (Giddens, 1984) that associates an economic and sociological approach on the success of enterprises (Granovetter, 1973). Social embeddedness into business relies on social class or status to some extent (Granovetter, 1985; Jack, 2005). In this latter respect, immigrant entrepreneurs are in a disadvantageous position in the business market (Yeasmin 2016) which necessitates social cohesion and inclusion in the host country (Ibid.) Social companionship requires ties between all relevant actors and sectors of society.

Institutional dimension: Institutional aspects indicate a macro embeddedness perspective to business. A different institutional framework generates a long and continuous learning path for immigrant entrepreneurs. Therefore, the institutional embeddedness in the opportunity structure creates a complex and, to some extent, underdetermined situation among entrepreneurs. Institutional embeddedness affects the opportunity structure of low-skilled immigrant entrepreneurs (Yeasmin, 2016), as micro-level enterprises, where the entrepreneur is the only employee of the business, have no capacity for learning institutional opportunity.

There are four factors in an institutional framework that may affect the opportunity structure. I) Ways of opportunities that depend on the welfare society, sincedifferentwelfare regimes offer differentfacilitiesthatcanconstrain or extend market provision of social reproduction. This institutional obstacle can create opportunity or can block the market for immigrant entrepreneur. II) Labour market regulations can be promising or less promising for aspiring immigrant entrepreneurs. There are sharp divisions in some state regulations between locals and immigrants, which can hinder the opportunity structure 
for immigrant entrepreneurs. III) Regulations for regulating business such as controlling business opening hours, range of products, business location, size and type of office accommodations, skill requirements and educational qualifications for entrepreneurs or employees. IV) In some communities, the business system very much depends on relationships between economic actors. Some economic actors are dominating the business market and shrinking some opportunities for immigrant entrepreneurs who are outsiders in the host country. Institutional barriers could be a threat to the business inclusion for micro-enterprises and their embeddedness. Institutional law and order, formal-informal norms and policies necessitate a threshold of knowledge about the institutional structure of the host country and society. Institutional embeddedness requires the entrepreneur to know about various economic actors and sectors for business collaboration, which brings the potential for business growth, and to know about various business systems, e.g., state-organized or arranged by the community, etc.

Institutional dimension in CSR indicates a legitimate managerial behavior of enterprise within the framework of public policies, which are relevant in practice (Garigga \& Melé, 2004). In CSR, public policies mean not only the literal text of law and regulations but also some social customs reflected through public opinion, the issues that can emerge through public discourse, and the implementation of public opinion in practice (Preston \& Post, 1981, p. 57; Jenkins, 2006), are the principles of public responsibility. As mixed embeddedness, CSR also includes lobbying, coalition building, corporate public affairs, stakeholder management and relationship policies (Vogel, 1986). Establishing stakeholder dialogue support is necessary to address many unclear signals in the business environment (Kaptein \& Van Tulder, 2003). Usually, micro-businesses can be involved in irresponsible business practices related to the workplace, consumer rights, safety, human rights, and the environmental context (Azmat \& Samaratunge, 2009).

CSR requires informal codes of conduct for operating rules or ecological promises for posturing environmental issues in collaboration with stakeholders. For a micro-scale business, energy savings, preservations of product, waste disposal, recycling, pollution and health \& safety policies (UN 2009) are all incorporated actions required from the entrepreneur. All those combining dimensions of CSR and mixed embeddedness require internal and external determinants from immigrant entrepreneurs to discover opportunity structures. CSR practice or embeddedness of mixed practices entails an effort from the immigrant business. Lack of clarity to those opportunity aspects and understanding CSR and mixed embeddedness narrow their business operating skills to some extent. 


\section{METHODOLOGY}

This research work is based on five case studies on five immigrant entrepreneurs in Rovaniemi and the material is collected through 1) ethnographic observation, 2) semi-structured in-depth interviews and 3) theory analysis. The ethnographic observation was conducted between 2014 and 2018. The semi-structured in-depth interviews of two successful entrepreneurs were done in 2013. These two entrepreneurs have been successfully running their business for many years and have established a good reputation in immigrant entrepreneurial life in Rovaniemi. One of the authors of this study has been spending many hours with immigrant entrepreneurs for ethnographic observations with the remaining three entrepreneurs for collecting data and research materials.

Unstructured data from ethnographic observation was collected from direct engagement through informal conversations, community meetings, and involvement with their daily activities to some extent. The observation yields some more insights of their business lives that maybe wouldn't have been possible to discover by asking questions, due to language barriers between respondents and researchers, therefore sometimes it is easier and more understandable by observing respondents and their business activities. Although it is more time consuming than interviewing, the output is more credible.

In data analysis, the study emphasizes and categorizes themes and key issues. The main themes are narrated in accordance with theoretical explanations based on empirical insights. After data triangulation, the study highlights the collected data and how the entrepreneurial integration of the immigrant relates to CSR and the mixed embeddedness theory. Collected data and materials suggest that the integrated theory and its aspects facilitate and open up nodes of entrepreneurial integration of immigrants in Lapland. The enterprises in this study are micro level as they have less than 10 employees (European Commission, 2012; 2003). The entrepreneurs are from different parts of the world and have different socio-cultural and political backgrounds. Their origins are different and so are their age groups and business field. Rovaniemi is a very small city and, as everybody knows each other, it is difficult to expose their business field as it is recognizable. Usually, immigrants operate restaurant businesses, groceries, pizza shops, massage parlors, coffee shops, etc.

Four out of 5 respondents are male (M) and one is Female (F) and mostly they are middle-aged. 
Table 1. A material collection

\begin{tabular}{|c|c|c|c|c|}
\hline Cases & Method & $\begin{array}{l}\text { Time of material } \\
\text { collection }\end{array}$ & $\begin{array}{l}\text { Original } \\
\text { background }\end{array}$ & $\begin{array}{l}\text { Gender/Age } \\
\text { group }\end{array}$ \\
\hline $\begin{array}{l}\text { Case B } \\
\text { Bob }\end{array}$ & $\begin{array}{l}\text { Ethnographic observation } \\
\text { and in-depth interview }\end{array}$ & 2014-2018 & Asia & $\mathrm{M} / 30-40$ \\
\hline $\begin{array}{l}\text { Case T } \\
\text { Tom }\end{array}$ & In-depth interview & 2013 & Europe & $M / 40-60$ \\
\hline $\begin{array}{l}\text { Case S } \\
\text { Sadaf }\end{array}$ & $\begin{array}{l}\text { Ethnographic observation } \\
\text { and in-depth interview }\end{array}$ & $2015-2018$ & Africa & $\mathrm{M} / 30-40$ \\
\hline $\begin{array}{l}\text { Case C } \\
\text { Camelia }\end{array}$ & In-depth interview & 2013 & Europe & $\mathrm{F} / 30-40$ \\
\hline $\begin{array}{l}\text { Case } \mathrm{P} \\
\text { Payman }\end{array}$ & Ethnographic observation & $2014-2018$ & Middle-East & $\mathrm{M} / 50-70$ \\
\hline
\end{tabular}

In theory triangulation phases, we analyze our materials on the basis of opportunity recognition; how entrepreneurs perceive a possibility of improving an existing business. The basic three concepts of opportunity recognition are 1) perception, 2) discovery and 3) creation which can support entrepreneurs to match their resources with market needs. Our original dataset has been analyzed for coherent study-clustering. As our two theories address economic, social and institutional opportunity recognition we, therefore, analyze only those data that interpret and support our theories. On the other hand, both competing theories also help us to strengthen our data. Our empirical materials also show that immigrant entrepreneurship success in Lapland is not only influenced by the resources of entrepreneurs (competences, skills, capital) but also by the institutional regime, economies and social structure in the host country of the diaspora. Opportunities need to be embedded to get access to the necessary capital. The integrated concept of two business theories investigates the relevance between each other and enables an explanation to be provided on economic, social and institutional opportunity recognition amongst immigrant entrepreneurs in Lapland.

\section{RESULTS AND DISCUSSION}

Small, immigrant entrepreneurs lack resources and social and human capital in Lapland. Some of the respondents have pretty little knowledge of the CSR concept (Case B - Bob and Case P - Payman) whereas some others thought that CSR is very much related to larger companies and their philanthropic characteristics (Tom, Camelia \& Sadaf), and they agreed that their businesses are small-sized, but they do not have a perfect knowledge about the definition 
of a small-scaled business. Business governance strategy means a large timeconsuming issue for the respondents in the first expression, which they do literally in unwritten form and unknowingly (Belal, Payman \& Sadaf). Usually, they lack lead-time in small and micro companies as they have to work full time in their companies (Belal, Sadaf \& Payman). They do not have any intermediaries to execute such initiatives. Therefore, small companies lack the ideal settings for CSR and sustainability because they require flexible management systems and corporate governance (Belal, Sadaf \& Payman).

All the respondents believe that a lot of effort is needed at the beginning of the business to get public visibility and make the business a brand among customers. Business needs several strategic plans, goals and motivations for branding and getting visibility (Tom, Sadaf \&Camelia) which are not necessarily in written form (Tom, Sadaf, Belal, Payman \& Camelia). In most instances, a business run by an individual owner has planned a strategy on an instant basis. They take factual decisions instantly and, in most instances, the customer is their main priority. They believe that business success only depends on good customer service (Sadaf, Camelia \& Tom), not about situational market analysis which is time-consuming. Strategic flexibility, social and human capital are indirectly related to customer services and business success. Unconsciously, they need to follow mixed embeddedness to offer good customer service. They do have surface knowledge (Belal, Sadaf and Payman) which means a level of understanding the meaning of entrepreneurial knowledge that has been created via logic, analysis, observation, reflection and prediction (Bennet \& Bennet, 2008). Tom and Camelia have a shallow knowledge (Bennet \& Bennet 2008) on entrepreneurship, which means contextual understanding, meaning and sense-making. However, all of the respondents lack deep knowledge on entrepreneurial success that depends on economic, social and institutional interplay.

We have discussed the immigrant entrepreneurs' perspective towards three opportunity recognition dimensions that can interconnect our theoretical perspectives as well, I) economic dimension, II) social dimension and III) institutional dimension. These can support us in exploring our findings according to our research questions for understanding the drivers of opportunity recognition.

\section{Economic opportunity context}

Lwimited human capital blocked various opportunities for the growth potential of immigrant entrepreneurs. Human capital in the forms of education, experiences, personal attributes and integrity support the orientation of entrepreneurs towards the market in Lapland. Bob and Payman have run their 
businesses for more than three years, but lack many opportunities relating to creating profit and value in an enterprise. They had experience of working in a similar kind of enterprise before they established their businesses, yet they have little knowledge about business strategy, e.g., designing a supply chain, good consumer service, and relationships towards stakeholders.

Personal attributes towards all related stakeholders require a common communication language. In the Bob and Payman cases, we found that their common language skills are English and Finnish and both are too weak for business communication. They serve their customers by knowing their needs and increase relations with stakeholders, which is not only limited to generic economic functions. In both cases, an alternative explanation of their business success is their experience of prior working in a similar working place. They know the market competition, e.g., pricing and cost; their business attracts both ethnics and locals and they have the physical fitness to work hard. Bob attracts more locals than Payman; Bob also attracts a small group of tourists. Their business success does not create any enormous profit for them; it just creates value. They lack utilizing capacity of existing support because they lack lead-time to utilize such opportunities. They lack negotiation and marketing skills as they lack prior entrepreneurial knowledge and skills.

The human capital of Tom \& Camelia helps them find various opportunities and make them successful in the Lappish market. They have both run their business for more than 10 years in Lapland. Camelia has prior entrepreneurial education at the university level. Tom has achieved supplementary entrepreneurial education immediately after establishing his business. Therefore, encompassing economic and non-economic goals, e.g., relations and networking between different groups of stakeholders, competency to know market competition, pricing and cost, monitoring market, utilizing the capacity of existing support on human resources, negotiation and marketing towards creating profit and values have helped them sustain their business. Their Finnish language skills indeed back up mixed embeddedness. Sadaf lacks entrepreneurial education, although he has other formal education and language difficulties are not identified as the biggest barriers in the case of Sadaf. He has a good command of English and Finnish. Therefore, language does not create a big barrier for business communication. He lacks lead-time to search for or utilize existing opportunities. Sadaf's business product attracts different ethnic groups, which limits the number of local consumers. He has been motivated to establish a business by peer-role model. He has operated the business for three years and has been facing start-up problems until now. He lacks time for ongoing entrepreneurial education that could support recognizing the benefit and values of the business. The business position of Sadaf is survival but not successful yet. According to the integrated concepts. 
Table 2. Assessment of economic context

\begin{tabular}{llllll}
\hline $\begin{array}{l}\text { Embeddedness Case B } \\
\begin{array}{l}\text { Economic } \\
\text { dimension }\end{array}\end{array}$ & $\begin{array}{l}\text { Case T } \\
\text { (Bom) }\end{array}$ & $\begin{array}{l}\text { Case S } \\
\text { (Sadaf) }\end{array}$ & $\begin{array}{l}\text { Case C } \\
\text { (Camelia) }\end{array}$ & $\begin{array}{l}\text { Case P } \\
\text { (Payman) }\end{array}$ \\
\hline $\begin{array}{l}\text { Human capital } \\
\text { Behavioral }\end{array}$ & $\mathrm{H} 4$ & $\mathrm{H} 1$ & $\mathrm{H} 2$ & $\mathrm{H} 1$ & $\mathrm{H} 3$ \\
\hline $\begin{array}{l}\text { economics } \\
\text { Market } \\
\text { orientation }\end{array}$ & $\mathrm{H} 3$ & $\mathrm{H} 1$ & $\mathrm{H} 2$ & $\mathrm{H} 1$ & $\mathrm{H} 4$ \\
\hline $\begin{array}{l}\text { Utilizing } \\
\text { opportunity }\end{array}$ & $\mathrm{H} 5$ & $\mathrm{H} 1$ & $\mathrm{H} 3$ & $\mathrm{H} 1$ & $\mathrm{H} 4$ \\
\hline Profit & $\mathrm{H} 3$ & $\mathrm{H} 1$ & $\mathrm{H} 3$ & $\mathrm{H} 2$ & $\mathrm{H} 5$ \\
\hline Lead-time & $\mathrm{H} 0$ & $\mathrm{H} 2$ & $\mathrm{H} 4$ & $\mathrm{H} 2$ & $\mathrm{H} 3$ \\
\hline
\end{tabular}

Note: Success levels: 5 - poor condition, 4 - inadequate, 3 - manageable, 2 - feasible, 1 - satisfactory, 0 - not available ( $\mathrm{H}$ - high).

In all cases, they are continuing their business although they have mixed business embeddedness towards economic success. In some cases, success requires relatively high-skilled human capital and in some others, business growth comes through small-scale and informal embeddedness, low-skilled human capital and physical fitness for sustaining long hours of hard work because of their age group. However, we found that the propensity for risk and opportunities of economic cycle among Sadaf, Bob and Payman which are at the "manageable" and "inadequate" level, suggest they embed their entrepreneurial knowledge and skills to ease their access to economic capital. Growth aspirations among Tom \& Camelia are feasible and satisfactory since exploring mixed embeddedness of growth potential is high.

\section{Social opportunity context}

Relations between society and entrepreneurs are mainly micro-social in our cases. The entrepreneurs find that they do not want to create any philanthropic responsibilities between society and enterprises on a larger-scale. They follow a normal, authentic norm of attitudes and rational behavior with the community and specific ethnic community members. They hold a common good for society. Their social obligation, interpretation of common good, the definition of positive contribution and well-being vary depending on their socio-cultural background, and they follow a harmonic way to live together in the society. They pay taxes and have created employment for themselves for the common good of society, though their integration processes are different.

Tom and Camelia are Europeans and have very close socio-cultural characteristics with locals and they can understand the local economic sector better than Bob, Sadaf and Payman. The socio-cultural background of these 
entrepreneurs gives them an advantage in their integrating process into society in Lapland. The market dependency on Tom and Camelia relies on both ethnic and local resources. They have strong networks with different ethnic groups, European immigrants and locals. On the other hand, Bob, Sadaf, and Payman are from very different socio-cultural backgrounds than local Finns and that has an impact on their business integration. Bob, Sadaf and Payman are willing to adjust their home country culture and customs and family values, and they maintain good relations with the members of similar language groups in Lapland, as it is easier for them to speak the same language with their peers from the same country. They still try to maintain some weak or strong linkage with their background culture which they also express in the business dealings with customers and stakeholders.

They have a strong peer network; different ethnic networks and their Finnish network is weaker than that of Tom \& Camelia. It has either a positive or a negative impact on operating a business in Lapland. In some cases, entrepreneurial performance according to their own heritage culture does not necessarily attract host people in business performance. Their service style could be acceptable for co-ethnic customers, but not for Finns. Bob, Sadaf and Payman usually depend on a variety of ethnic capital by searching for employees or interns and customers from the ethnic community. It can help their internal business. However, it does not support their acculturation with mainstream society.

On the contrary, Sadaf gets business support from their peer network, both nationally and internationally. For example, most of his suppliers are from Holland and Sweden and belong to a similar ethnic group. Common business ethics between his peer stakeholders facilitates trustworthiness between Sadaf and his national and international supplier.

The majority of the customers of Payman and Sadaf are members of marginalized racial and ethnic groups who are segregated from the local mainstream network. The socio-cultural networks of Tom and Camelia support them getting business visibility. The advancement of the technical know-how of Tom and Camelia is socially constructed (Kloosterman \& Rath, 2001), since they embed Finnish culture into their business (e.g., the interior design of their business place, applying a specific kind of service design that embeds and combines Finnish culture with an ethnic business) and they pay attention to the demand side of the ethnic and non-ethnic stakeholders.

Social networking increases know-how on integrating social demands and ethical obligation to society. The responsibility and accountability towards social effect are paid little attention by Bob, Sadaf and Payman since CSR is contextual and a social-cultural orientation, which differs in their countries of origin. The influence of CSR is an unknown perception in some of their 
host countries. Interestingly, they practice CSR without being aware of the notion. Although they don't know that they are socially responsible, Bob and Sadaf show a charitable, giving behavior. Bob sponsors, through micro-social resources, the multicultural community for the well-being of immigrants residing in Rovaniemi, while Sadaf donates a small amount of money to a youth society and to the Salvation Army organization for the well-being of youth and vulnerable people. They cannot pay full attention to charitable social issues with larger resources since the businesses are smaller and must survive.

The social network of Tom and Camelia controls access to social monitoring skills over business opportunity. As a social obligation, Tom recruits long-term unemployed as employees or interns in his business to reduce the social burden to some extent. Some support other social initiatives, e.g., distributing food among the poor and supporting the well-being of a specific ethnic group by incorporating small social impact projects at a micro-social level. However, others are inactive and do not adopt philanthropic activities.

\section{Institutional opportunity context}

The role of an institutional framework in mixed embeddedness can enable or constrain immigrant entrepreneurship. Whether or not the entrepreneurial success of an immigrant is influenced by institutional settings (legal and political restrictions) is an extended view of business opportunity (Volery, 2007). A European immigrant gets more institutional freedom than other immigrant groups since two major advantages are the freedom to establish a business within the EU and easier recognition of qualifications (Hermes \& Leicht, 2010).

Table 3. Underpinnings of social embeddedness

\begin{tabular}{llllll}
\hline $\begin{array}{l}\text { Social } \\
\text { embeddedness }\end{array}$ & $\begin{array}{l}\text { Case B } \\
\text { (Bob) }\end{array}$ & $\begin{array}{l}\text { Case T } \\
\text { (Tom) }\end{array}$ & $\begin{array}{l}\text { Case S } \\
\text { (Sadaf) }\end{array}$ & $\begin{array}{l}\text { Case C } \\
\text { (Camelia) }\end{array}$ & $\begin{array}{l}\text { Case P } \\
\text { (Payman) }\end{array}$ \\
\hline $\begin{array}{l}\text { Social network } \\
\mathrm{W}^{*}\end{array}$ & $\mathrm{~S}^{* *}$ & $\mathrm{M}^{*}$ & $\mathrm{M}^{* *}$ & $\mathrm{~W}^{*}$ \\
\hline $\begin{array}{l}\text { Mutual trust } \\
\text { Social status }\end{array}$ & $\mathrm{W}$ & $\mathrm{M}$ & $\mathrm{W}$ & $\mathrm{S}$ & $\mathrm{W}$ \\
\hline $\begin{array}{l}\text { Philanthropic } \\
\text { activities }\end{array}$ & $\mathrm{W}^{*}$ & $\mathrm{M}^{* *}$ & $\mathrm{~W}^{* *}$ & $\mathrm{I}$ & $\mathrm{I}$ \\
$\begin{array}{l}\text { Social awareness / } \\
\text { justice }\end{array}$ & $\mathrm{W}^{*}$ & $\mathrm{M}^{* *}$ & $\mathrm{~W}^{*}$ & $\mathrm{M}$ & $\mathrm{W}^{*}$ \\
$\begin{array}{l}\text { Integration to } \\
\text { society }\end{array}$ & $\mathrm{M}^{* *}$ & $\mathrm{~S}^{* *}$ & $\mathrm{M}^{*}$ & $\mathrm{~S}^{* *}$ & $\mathrm{M}^{*}$
\end{tabular}

Note: $\mathrm{S}=$ strong; $\mathrm{M}=$ medium; $\mathrm{W}=$ weak; $\mathrm{I}$ : inactive *Ethnic based with different ethnic groups; **Diverse with all ethnic(s) and locals. 
The institutional system and legal barriers for accreditation of qualification from non-EU immigrants are mostly seen as a way of forcing them into self-employment. For instance, Bob started a business due to the restricted access to jobs and limited opportunities for upward mobility in the jobs available to them. Tom and Camelia have been somehow motivated to become entrepreneurs. Tom has a European education, which is easily accredited in Finland. There was no educational accreditation problem for Camelia, as she completed her education in Finland. Payman started his business on the basis of demand in an advancing economy and increasing his social status, while Sadaf was encouraged by a peer role model.

On the other hand, immigrants lack awareness about business law and regulations in the host country. They also lack clear information about different financial schemes like trust funds, soft loans, local enterprise funds or lease of buildings, etc. Bob, Payman and Sadaf lack service and guidance agencies. There is a guidance agency to support start-up businesses but support is unavailable during operational turbulences in the businesses. There are entrepreneurial boards in Lapland; however, representation requires some financial resources from the micro-immigrant entrepreneurs. Tom and Camelia have not been participating in any entrepreneurial boards; however, their comparatively strong social networks support them to get clear information about financial schemes. Business support processes are very bureaucratic and they also require strong professional skills.

Tax regulation, labor law and social security obligations are the same for all regardless of the size and age of the business, and this requires tailored counseling and assistance. Bob, Payman and Sadaf cannot take part in entrepreneurial courses offered by a governmental organization, since they do not have the human resources to substitute them during the course period. Even if they wanted to manage some substitute employees, there is a language barrier to understanding the lessons that are mostly provided in Finnish. They also lack formal and informal communication methods about such programs and courses.

According to Tom and Camelia, usually, there are no general policies by government organizations of sending messages to entrepreneurs to inform them that such courses are available. There is much to reform concerning the general rules and regulations on business performance. The attitude of the city towards immigrant business has an important role in making the business policies familiar to immigrant entrepreneurs. Bob, Payman and Sadaf lack all facilities from credit institutions and do not have access to other unconventional finance such as loans from credit unions. Many larger organizations use lunch vouchers as a payment instrument for their employees. These lunch vouchers, chip cards, recreational cards, dual wallet cards or transportation card payment 
methods require institutional knowledge and information that immigrants lack. The companies who offer those different cards provide merchant benefits, which are difficult for immigrant micro-entrepreneurs to participate in. Bob emphasized several times this unwanted difficulty to get accurate information about the use of those lunch cards.

Therefore, matching opportunities with resources necessitates upgrading their exploitative and explorative knowledge about the unstable institutional framework. The entrepreneurs' attention towards institutional embeddedness changes the outcome of the business. Bob, Payman and Sadaf lack alliances between public and private sectors because there is no governmental body to regulate those alliances. To some extent, Camelia lacks regulatory bodies that can advise entrepreneurs and demand short corporate reporting yearly. Regulatory bodies can get practical knowledge and entrepreneurs' views through a corporate reporting system, whilst in return, enterprises get an opportunity to share their concerns and this might relieve some institutional pressure on entrepreneurs by sharing knowledge. Camelia expects credible strategic policies and coordinated efforts from the regulatory bodies.

According to Camelia, Tom and Sadaf, CSR practice should be coordinated and stimulated by a public body so that they might expand their understanding of institutional agendas. Embedding with a state institution can sustain the business. As, according to Tom, identifying an opportunity on public procurement law would help sustain his business in Lapland. The CSR concept (e.g., supplier diversity and inclusive purchasing) can embed an opportunity to a minority group through increasing interaction with a supplier, who is a larger organization and a primary stakeholder of Tom's. Tom embeds opportunities by making a sub-contract with a primary stakeholder, e.g., a municipality. Maintaining stakeholder relations with a larger institution would facilitate obtaining information for Tom and it would help in knowing where to get some particular information.

Legitimate managerial behavior of enterprise exists in the case of Tom and Camelia, for example, they can follow public opinion, public discourse about law and regulation, and understand coalition building, public affairs, as well as stakeholder management, comparatively better than other entrepreneurs do. Additionally, according to Tom and Camelia, there is stakeholder dialogue support to address many unclear signals from their businesses. However, the rights of consumers, safety, human rights, and other environmental contexts of CSR, are partly very difficult to understand for Tom and Camelia. By comparison, Bob, Payman and Sadaf have little or no knowledge about the environmental context of CSR and related rights. 
Table 4. Situational assessment on institutional embeddedness

\begin{tabular}{|c|c|c|c|c|c|}
\hline $\begin{array}{l}\text { Institutional } \\
\text { embeddedness }\end{array}$ & Case B & Case T & Case S & Case C & Case P \\
\hline Overall institutional settings & $\mathrm{X} 1$ & $X 4$ & $\mathrm{X} 1$ & X3 & $\mathrm{X} 2$ \\
\hline $\begin{array}{l}\text { Identifying and matching } \\
\text { institutional opportunities }\end{array}$ & X0 & X3 & $\mathrm{X} 1$ & $\mathrm{X} 2$ & XO \\
\hline Institutional awareness & $\mathrm{X} 2$ & X3 & $\mathrm{X} 2$ & X3 & $\mathrm{X} 2$ \\
\hline $\begin{array}{l}\text { Legitimate managerial behaiour/ } \\
\text { governance }\end{array}$ & $\mathrm{X} 2$ & $X 4$ & $\mathrm{X} 2$ & X4 & $\mathrm{X} 1$ \\
\hline Exploring institutional obligation & $\mathrm{X} 1$ & X3 & $\mathrm{X} 2$ & X3 & $\mathrm{X} 1$ \\
\hline Stakeholder management policy & $\mathrm{X} 2$ & X4 & X3 & $\mathrm{X} 4$ & $\mathrm{X} 2$ \\
\hline Human rights contexts & $\mathrm{XO}$ & X3 & $\mathrm{X} 1$ & X3 & $\mathrm{X} 1$ \\
\hline
\end{tabular}

Note: $\mathrm{X} 1=$ inadequate, $\mathrm{X} 2$ = manageable, $\mathrm{X} 3=$ feasible, $\mathrm{X} 4$ = satisfactory; $\mathrm{X}=$ poor.

\section{CONCLUSIONS}

The study argues that there is no uniform model for measuring the success factors of immigrant entrepreneurs because immigrant entrepreneurs are of a diverse nature. They are from different socio-cultural, political and economic backgrounds, and this can have an effect on the success or failure of a specific policy targeting immigrant entrepreneurship. There are mixed advantages and disadvantages that affect business success or failure. Super mixed embeddedness reinforces the entrepreneurial path of immigrants in Lapland. The adjustment of demand and supply by assessing the needs of the immigrant entrepreneurs is, therefore, a dynamic process.

The success of immigrant businesses is also conditioned by the mixed provision of reliable service and business ethics. The ethical behavior of our respondents is supported by their mental culture (which is formed by their cultural heritage) and social culture (which is partly formed by the receiving culture). This bi-dimensional orientation of ethical beliefs towards business cause mixed outputs in their businesses. Even though they, to some extent, choose the business ethics of their origin, they have the choice to choose both values and ethics in their business. Combining and utilizing both values in the business, in the right place, at the right time, entails an opportunity structure.

The study finds that mixed professional backgrounds also perform as an important contributor to business since some of our respondents are successfully operating a business despite not having an entrepreneurial education. Sometimes, some weak ties are considered valuable to strengthen 
strong ties. The combination of different mixed ties does not necessarily block business aspiration; it might open a different opportunity path for business success. An individual entrepreneur can have a strong degree of some factors and a weak degree of others. These strong and weak factors correlate with entrepreneurial opportunity recognition (Granovetter, 1985; Xiaodan et al., 2010). Although strong ties have influential values in entrepreneurship, weak ties can also be innovative and dynamic.

All the entrepreneurs in our study have run their businesses for more than three years, and that is hard in Lapland. Usually, immigrant entrepreneurs have to shut their businesses within one year of opening in Lapland (Yeasmin, 2016). In this transitional phase, our study respondents have been successfully operating their business with mixed embeddedness. Our respondents are creating new forms of embeddedness for sustaining their business even if they don't know that their own creations are informal economic activities along with different domains of embeddedness. Their strong sides include good customer service, a hard-working nature, a level of confidence and a willingness to learn.

Their weak sides are, e.g., information acquisition, opportunity recognition; their weak ties are influenced by their strong ties. Some respondents think that word-of-mouth recommendations can attract and retain customers since they do not have the resources for marketing; informal stakeholder relationships, oral and instant strategy rather that written or legal provision, can be the cause of success or failure in some cases.

According to our study, CSR and mixed embeddedness lack any particular, universally understood meaning. Although some of our study respondents have little knowledge about CSR, they are somehow exercising those contexts in practice unconsciously. Their perceptions and practices of CSR include mixed propositions. They might be able to operate a successful business even better if they could get precise propositions of stakeholder theory, conceptions on human capital in business, institutional and social embeddedness. Particular understanding can make them aware of the importance of managing CSR and the importance of mixed embeddedness in business behavior. Familiarization with the ecological environment can play a significant role for individual and business sustainability, which has been paid little attention to by our respondents. If the surface and shallow knowledge (weak ties) are good for survival, deep knowledge (strong ties) is also significant for sustaining a business.

This research also has some limitations. The sample of the analysis is so small that the results cannot be generalized. Equally, as Rovaniemi is such a small city, the country of origin of the respondents cannot be divulged as this 
would make them recognizable. Therefore, this limits the analysis to clarify the ethnic backgrounds of the respondents in the methodology part of the study.

\section{References}

Azmat, F., \& Samaratunge, R. (2009). Responsible entrepreneurship in developing countries: Understanding the realities and complexities. Journal of Business Ethics, 90(3), 437-52.

Azmat, F., \& Zutshi, A. (2012). Influence of home country culture and regulatory environment on corporate social responsibility (CSR) perceptions: The case of Sri Lankan immigrant entrepreneurs. Thunderbird International Business Review, 54(1), 15-27.

Baycan-Levent, T., Nijkamp, P. (2009). Characteristics of migrant entrepreneurship in Europe. Entrepreneurship \& Regional Development, 21(4), 375-397.

Beekun, R.I., \& Badawi, J.A. (2005). Balancing ethical responsibility among multiple organizational stakeholders: The Islamic perspective. Journal of Business Ethics, 60, 131-145.

Bennet, D. \& Bennet, A. (2008). The depth of knowledge: Surface, shallow or deep? VINE, 38(4), 405-42.

Coombs, W.T., \& Holladay, S.J. (2012). Managing Corporate Social Responsibility: A Communication Approach. West Sussex: Wiley-Backwell.

Crane, A., Matten, D., \& Moon, J. (2004). Stakeholders as citizens? Rethinking rights, participation, and democracy. Journal of Business Ethics, 53, 107-122.

Davis, K. (1960) Can business afford to ignore corporate social responsibilities? California Management Review, 2, 70-76.

Den Hond, F., \& De Bakker, F.G. (2007). Ideologically motivated activism: How activist groups influence corporate social change activities. Academy of Management Review, 32, 901-924

Donaldson, T., \& Thomas, W.D. (2000). Précis for ties that bind. Business and Society, 105, 436- 444.

Elfring, T., \& Hulsink, W. (2004). The Strong versus weak tie effect on entrepreneurial processes: ICT-Start-ups in the Netherlands. Retrieved from https://library.wur.nl/WebQuery/wurpubs/fulltext/45571

European Commission. (2003). Building the Information Society in Europe: A Pathway Approach to Employment Interventions for Disadvantaged Groups. Dublin: Itech Research.

European Commission. (2012). Enterprise and Industry SME Definition. Retrieved 21 February, 2012, from http://ec.europa.eu/enterprise/ policies/sme/facts-figures- analysis/sme-definition/index_en.htm

Frederick, H.H. (2006). Global entrepreneurship monitor, Aotearoa New Zealand. Unitec School of Management \& Entrepreneurship Research Report Series. Unitec New Zealand: Auckland, Retrieved from www. gemconsortium.org 
Frederick, H.H. (2008) Introduction to special issue on indigenous entrepreneurs, Journal of Enterprising Communities, 2(3), 185-191.

Garriga, E., \& Melé, D. (2004). Corporate social responsibility theories: Mapping the territory. Journal of Business Ethics, 53, 51-71.

Giddens, A. (1984). The Constitution of Society. Berkeley, California, USA: University of California Press.

Gjølberg, M. (2010). Varieties of corporate social responsibility (CSR): CSR meets the "Nordic Model." Regulation and Governance, 4, 203-229.

Goodpaster, K.E. (1999). Bridging East and West in management ethics: Kyosei and the moral point of view. In G. Enderle (Ed.), International Business Ethics. Challenges and Approaches (pp. 151-159). France: University of Notre Dame Press, Notre Dame.

Granovetter, M. (1985). Economic action and social structure: The problem of embeddedness. American Journal of Sociology, 91(3), 481-510.

Granovetter, M. (2005). The impact of social structure on economic outcomes. Journal of Economic Perspectives, 19, 33-50.

Granovetter, M. (1973). The strength of weak ties. American Journal of Sociology, 78(6),1360-1380.

Hamilton, R., Dana, L-P., \& Benfell, C. (2008). Changing cultures: An international study of migrant entrepreneurs. Journal of Enterprising Culture, 16(1), 89-105.

Handelman, J.M. (2006). Corporate identity and the societal constituent. Journal of the Academy of Marketing Science, 34, 107-114.

Hermes, K., \& Leicht, R. (2010). Scope and characteristics of immigrant entrepreneurship in Europe. A cross-national comparison of European countries. Retrieved 28 January,2018, from https://www.gesis. org/fileadmin/upload/institut/wiss_arbeitsbereiche/gml/ Veranstaltungen/5.NK_2007/Papers/Hermes_Leicht.pdf

Hjerm, M. (2004). Immigrant entrepreneurship in the Swedish welfare state. Sociology, 38(4),739-56.

Jack, S.L. (2005). The role, use and activation of strong and weak network ties: A qualitative analysis. Journal of Management Studies, 42(6), 1233-59.

Jenkins, H. (2006). Small business champions for corporate social responsibility. Journal of Business Ethics, 67(3), 241-56.

Juholin, E. (2004). For business of the good of all? A Finnish approach to corporate social responsibility. Corporate Governance, 4(3), 20-31.

Kaku, R. (1997). The path of Kyosei. Harvard Business Review, 75(4), 55-62.

Kaptein, M., \& Van Tulder, R. (2003). Toward effective stakeholder dialogue. Business and Society Review, 108, 203-225.

Keinert, C. (2008). Corporate Social Responsibility as an International Strategy. Germany: Physica-Verlag, Heidelberg.

Kloosterman, R., \& Rath, J. (1999). Mixed embeddedness. (In)formal economic activities and immigrant business in the Netherlands. International Journal of Urban and Regional Research, 23(2), 253-267. 
Kloosterman, R., \& Rath, J. (2001). Immigrant entrepreneurs in advanced economies: Mixed embeddedness further explored. Journal of Ethnic and Migration Studies, 27,189-202.

Kloosterman, R. (2010). Matching opportunities with resources: A framework for analysis (migrant) entrepreneurship from a mixed embeddedness perspective. Entrepreneurship and Regional Development, 22(1), 25-45.

Kotler, P., \& Lee, N. (2005). Corporate Social Responsibility: Doing Most Good for Your Company and Your Cause. Hoboken, New Jersey: John Wiley \& Sons. Inc.

Mahon, J.F., \& McGowan, R.A. (1991). Searching for the common good: A process-oriented approach. Business Horizons, 34(4), 79-87.

Melé, D. (2002) Not only Stakeholder Interests. The Firm Oriented toward the Common Good. France: University of Notre Dame Press.

Migration Policy Group (2002). Supplier diversity-the case of immigrant and ethnic minority enterprises. Paper prepared for the Transatlantic Round Table on Supplier Diversity. Brussels, Belgium.

MIT, Massachusetts Institute of Technology (2011). Sustainability: The 'embracers' seize the advantage. MIT Sloan Management Review. Retrieved from http://c0426007.cdn2. cloudfiles.rackspacecloud.com/ MIT-SMR-BCG-sustainability-the-embracers-seize-advantage-2011.pdf

Moravčíková, K., Stefanikova, L., \& Rypáková, M. (2015). CSR reporting as an important tool of CSR communication. Procedia Economic and Finance, 26, 332-338.

Mohamed, A., \& Leponiemi, J. (2009). Immigrant workers' induction training in Finland: Case Petmo project. Management of Environmental Quality: An International Journal, 20(3), 278-289,

Nelson, J., \& Prescott, D., (2003). Business and the millennium development goals: A framework for action. International Business Leaders Forum. Retrieved from http://www.centroscomunitariosdeaprendizaje.org.mx/sites/default/ files/business_and_the_millennium_development_goals.pdf

Pirsch, J.., Gupta, S., \& Grau, S.L. (2007). A framework for understanding corporate social responsibility programs as a continuum: An exploratory study. Journal of Business Ethics, 70, 125-140.

Polanyi, K. (1968). The economy as instituted process. In E. LeClair \& H. Schneider (Eds). Economic Anthropology (p. 126). New York: Holt, Rinehart and Winston.

Portes, A. (1995). Transnational communities, their emergence and significance in the contemporary world system. Working paper series \#16. Baltimore, MD: Johns Hopkins University.

Preston, L.E., \& Post, J.E. (1981). Private management and public policy. California Management Review, 23(3), 56-63.

Preuss, L. (2011). On the contribution of public procurement to entrepreneurship and small business policy. Entrepreneurship and Regional Development, 23, 787-814. 
Price, M., \& Chacko, E. (2009). The mixed embeddedness of ethnic entrepreneurs in a new immigrant gateway. Journal of Immigrant \& Refugee Studies, 7(3), 328-346.

Ram, M., \& Smallbone, D. (2003). Supplier diversity initiatives and the diversification of ethnic minority businesses in the UK. Policy Studies, 24, 187-204.

Rashid, Md. Z.A., \& Ibrahim, S. (2002). Executive and management attitudes towards corporate social responsibility in Malaysia. Corporate Governance, 2(4), 10-16.

Rath, J., Kloosterman, R.t, Haberfellner, R., Ma, M.E., Wilpert, C., Razin, E., Magatti, M., \& Barrett, G. (2002). Working on the Fringes: Immigrant Businesses, Economic Integration and Informal Practices, an International Network. IMES, Edinburgh: University of Amsterdam.

Rath, J. (2005). Feeding the festive city. Immigrant entrepreneurs and tourist industry. In E. Guild, \& J. van Selm (Eds.), International Migration and Security: Opportunities and Challenges (pp. 238-253). London, UK: Routledge.

Rohweder, L. (2004). Yritysvastuu - Kestävää Kehitystä Organisaatiotasolla. Porvoo: WSOY.

Santos, F.M. (2011). CSR in SMEs: Strategies, practices, motivations and obstacles. Social Responsibility Journal, 7(3), 490-508.

Sulmasy, D.P. (2001). Four basic notions of the common good. St. John's Law Review, 75(2), 303-311.

Suutari, T., Lämsä, A.M., Lähdesmäki, M., \& Mattila, M. (2016). Immigrant labor market in rural business - A corporate social responsibility approach. Retrieved 20 January, 2018, from https://ec.europa.eu/migrantintegration/librarydoc/immigrant-labour-in-rural-businesses-acorporate-social-responsibility-approach

Swedberg, R. (1994). Markets as social structures. In N. Smelser \& R. Swedberg (Eds). The Handbook of Economic Sociology (pp. 255-28). Princeton, New York: Princeton University Press/Russell Sage Foundation.

Taylor, M., \& Leonard, S. (2002). Approaching "embeddedness." In M. Taylor \& S. Leonard (Eds). Embedded Enterprise and Social Capital (pp. 1-18). Aldershot: Ashgate.

Uddin, M.B., Hassan, Md. R., Tarique, K. (2008). Three dimensional aspects of corporate social responsibility. Daffodil International University Journal of Business and Economics, 3(1), 199-212.

UN-United Nations (2009). The millennium development goals report 2009. Retrieved 12 December, 2011, from http://www.un.org/ millenniumgoals/reports.shtml

Velasquez, M. (1992). 'International business, morality, and the Common Good,' Business Ethics Quarterly, 2(1), 27-40.

Vogel, D. (1986). The study of social issues in management: A critical appraisal. California Management Review, 28(2), 142-152.

Volery, T. (2007). Ethnic entrepreneurship: A theoretical framework. In L.P. Dana (Ed.). Handbook of Research on Ethnic Minority Entrepreneurship. 
A Co-Evolutionary View on Resource Management (pp. 30-41). Cheltenham: Edward Elgar.

Waldinger, R., Aldrich, H., \& Ward, R. (1990). Opportunities, group characteristics, and strategies. In R. Waldinger, H. Aldrich, \& R. Ward (Eds.), Ethnic Entrepreneurs (pp. 13-48). London: Sage.

Wang, L. (2011). Factors affecting perceptions of corporate social responsibility implementation: An emphasis on values. Dissertationes Forestales. Retrieved from http://www.metla.fi/dissertationes/df130.htm

Xiaodan, G., Xingzhi, X., \& Wentao, H. (2010). Strong tie, weak tie and entrepreneurial opportunity recognition: The theory and testing by Chinese entrepreneur data. IEEE. Retrieved 27 January, 2018, from http://ieeexplore.ieee.org/document/5478231/?reload=true

Yamaji, K. (1997). A global perspective of ethics in business. Business Ethics Quarterly, 7(3), 55-71.

Yeasmin, N. (2016). The determinants of sustainable entrepreneurship of immigrants in Lapland: An analysis of theoretical factors. Entrepreneurial Business and Economic Review 4(1), 129-159.

\begin{abstract}
Abstrakt
Przedsiębiorcy imigranci funkcjonujq̨cy na terenie arktycznej Laponii znajdujq się w niekorzystnej sytuacji. Według dotychczasowych badań (Yeasmin, 2016) istnieje wiele czynników, które utrudniajq zrównoważony rozwój firm należqcych do imigrantów. Sa to m.in. brak wiedzy społeczno-ekonomicznej i politycznej. Poszerzanie wie$d z y$, łączenie silnych i słabych więzi (Granovetter, 1973) moga pozytywnie wpływać na rozwój biznesu. Zrównoważone praktyki przedsiębiorczości imigrantów wymagaja legitymizacji między działaniami przedsiębiorczymi a uznawaniem możliwości. Badania nad zrównoważonq przedsiębiorczościq imigrantów sq na razie poczq̨tkujacym obszarem badawczym i trudno jest stworzyć jeden model potencjału wzrostu przedsiębiorczości imigrantów w Laponii (Yeasmin, 2016). Dlatego celem tego badania jest stworzenie zintegrowanej wartości dla przedsiębiorców-imigrantów poprzez połq̨czenie CSR i teorii zakorzenienia oraz znalezienie alternatywnej koncepcji w celu zrozumienia czynników, które moga podtrzymywać funkcjonowanie mikroprzedsiębiorstw należq̨cych do imigrantów w Laponii. Badanie to dowodzi, że stopień rozwinięcia CSR można rozpatrywać jako czynnik wspierajqcy strategię instytucjonalnq, społecznq i gospodarczq. W badaniu Autorzy skupiajq się na czynnikach adaptacyjnych, które przedsiębiorcy-imigranci stosujq, aby przetrwać i osiqgać sukces przedsiębiorczy.

Słowa kluczowe: mieszane zakorzenienie, zrównoważenie, przedsiębiorczość, imigranci, CSR, rozpoznawanie szans
\end{abstract}




\section{Biographical notes}

Nafisa Yeasmin is a Post-doc Researcher. She devotes her studies to Arctic immigration in her Ph.D. research at the Arctic Centre of the University of Lapland. Her research interest includes how to understanding global migration governance at a regional level, and the challenges of migration governance to establish a greater coherence across the Arctic region. Special attention has been given to comprehensive governance strategies for accelerating the economic integration of immigrants since good governance reinforces economic integration that underpins the relative resilience of emerging economy in the global north. Nafisa works under the Arctic Governance Research Group. She has been involved with different national and international network on migration, such as the Sirius network. She has been leading the UArctic thematic network on Arctic Migration. She is also a distinguished member of the Finnish National Ethnic Advisory Board and has been the president of Arctic Immigrant Association. Additionally, she is also a member of several different steering committees directly involved with the integration of immigrants in the Arctic. Academically, Yeasmin has published several peer-reviewed articles in prestigious international journals. More information can be find here: https://lacris.ulapland.fi/en/persons/ nafisa-yeasmin(daf932e2-26aa-4ba2-a6c4-27336a3d527e).html

Timo Koivurova is a Professor. He has specialized in various aspects of international law applicable in the Arctic and Antarctic region. In 2002, Koivurova's doctoral dissertation "Environmental impact assessment in the Arctic: a Study of International Legal Norms" was published by Ashgate. Increasingly, his research work addresses the interplay between different levels of environmental law, the legal status of indigenous peoples, migration, the law of the sea in the Arctic waters, integrated maritime policy in the EU, the role of law in mitigating/adapting to climate change, the function and role of the Arctic Council in view of its future challenges, and the possibilities for an Arctic treaty. He has been involved as an expert in several international processes globally and in the Arctic region and has published articles on the topics mentioned above extensively. 